\title{
PENGARUH MODEL PEMBELAJARAN KOOPERATIF TIPE CRH BERBANTUAN MEDIA QUESTION CARD TERHADAP HASIL BELAJAR IPA
}

\author{
Tri Astuti ${ }^{1}$, I Wayan Suwatra ${ }^{2}$, I Made Tegeh $^{3}$ \\ 1,2 Jurusan Pendidikan Guru Sekolah Dasar, ${ }^{3} J u r u s a n$ TP, FIP \\ Universitas Pendidikan Ganesha, Singaraja, Indonesia \\ e-mail: astuti.trias17@gmail.com ${ }^{1}$, wayansuwatra@yahoo.co.id,
} im-tegeh@undiksha.ac.id ${ }^{3}$

\begin{abstract}
ABSTRAK
Penelitian ini bertujuan untuk mengetahui perbedaan hasil belajar IPA yang signifikan antara kelompok siswa yang dibelajarkan menggunakan model pembelajaran kooperatif tipe course review horay berbantuan media question card dan kelompok siswa yang dibelajarkan menggunakan model pembelajaran konvensional. Penelitian ini adalah penelitian semu (quasi eksperimen), dengan rancangan non equivalent posttest only control group design. Populasi penelitian ini adalah seluruh kelas III SD Gugus I Rinjani Kecamatan Melaya Kabupaten Jembrana yang berjumlah 114 siswa. Sampel pada penelitian ini adalah kelas III SDN 2 Gilimanuk berjumlah 24 siswa dan kelas III SDN 4 Gilimanuk berjumlah 20 siswa. Sampel ditentukan menggunakan teknik random sampling. Data hasil belajar dikumpulkan menggunakan tes pilihan ganda. Data yang diperoleh dianalisis menggunakan teknik analisis statistik deskriptif dan analisis statistik inferensial (uji-t). Hasil penelitian menunjukkan bahwa terdapat perbedaan hasil belajar IPA antara kelompok siswa yang dibelajarkan menggunakan model pembelajaran kooperatif tipe course review horay berbantuan media question card dan kelompok siswa yang dibelajarkan menggunakan model pembelajaran konvensional pada siswa kelas III SD Gugus I Rinjani Kecamatan Melaya Kabupaten jembrana. Hal ini ditunjukkan oleh $t_{\text {hitung }}(7,725)>t_{\text {tabel }}(2,021)$. Selanjutnya, rata-rata (mean) kelompok eksperimen $(19,08)$ lebih besar daripada rata-rata (mean) kelompok kontrol $(12,9)$. Dengan demikian, model pembelajaran kooperatif tipe course review horay berbantuan media question card berpengaruh positif terhadap hasil belajar IPA siswa kelas III SD Gugus I Rinjani Kecamatan Melaya Kabupaten Jembrana tahun pelajaran 2017/2018.
\end{abstract}

Kata Kunci : $\mathrm{CRH}$, question card, IPA

Abstract

The aims of this study is to determine the result differences in learning IPA (biology/science) between groups of students who are thought using cooperative model type course review horay using question card as a medium with group of students who are taught using conventional learning model.This research is quasi-experiment, with non equivalent posttest only control group design. The population of this research is the primary school students of grade 3 Gugus 1 Rinjani Melaya, Jembrana which is amounted to 114. 24 students of grade 3 in SDN 2 Gilimanuk and 20 students SDN 4 Gilimanuk were the sample of this study and was determined using random sampling technique. Learning result data is collected using multiple choice test. Statistical descriptive analysis technique and statistical inferential analysis (t-test) were used in analyzing the collected data. The results of study shows that there were differences of the result in learning IPA (science) between groups of students who were thought using cooperative model type course review horay using question card as a medium with group of students who were taught using conventional learning modelin third grade students of SD Gugus I Rinjani Melaya, Jembrana.This is shown by t-count $(7,725)>t$-table $(2.021)$. Furthermore, the average of experimental group (19.08) was bigger than the control group average (12.9). Thus, cooperative learning model type review course horay with question card as a medium have a positive effect on the resultin learning IPA (science)ofstudents in grade III SD Gugus I Rinjani Melaya, Jembrana of the academic year 2017/2018.

Keywords : : CRH, Question Card, IPA (science) learning result 


\section{Pendahuluan}

Sekolah Dasar merupakan salah satu lembaga formal pendidikan dalam struktur jenjang pendidikan nasional mengemban misi yang sangat strategis. Misi tersebut berkaitan dengan pengembangan sumber daya manusia (SDM) yang berkualitas, suasana belajar di sekolah dasar perlu direncanakan dengan menggunakan pembelajaran yang efektif. "Proses pembelajaran dikatakan efektif apabila seluruh peserta didik terlibat secara aktif baik mental, fisik, maupun sosialnya" (Susanto, 2013:53). Pembelajaran yang demikian harus terjadi pada semua mata pelajaran yang diterapkan di sekolah, termasuk pembelajaran IPA.

IPA merupakan mata pelajaran yang wajib diberikan di sekolah dasar. Mata pelajaran ini memegang peranan yang sangat penting dalam kehidupan sehari-hari.. IPA merupakan salah satu mata pelajaran pokok kurikulum pendidikan di Indonesia, termasuk pada jenjang sekolah dasar. Samatowa (2010:3) menyatakan bahwa "IPA atau science adalah ilmu tentang alam yang mempelajari peristiwa-peristiwa yang terjadi di alam ini". "Hal ini disebabkan karena kehidupan kita sangat tergantung dari alam, zat terkandung di alam, dan segala jenis gejala yang terjadi di alam" (Wisudawati \& Sulistyawati, 2015:22).

Pada pembelajaran IPA siswa harus terlibat aktif dalam proses pembelajaran yang diberikan oleh guru. Apabila pembelajaran IPA tidak memberikan pengalaman secara langsung kepada siswa, maka pembelajaran IPA akan sulit untuk diajarkan dan dipahami oleh siswa. Dalam pembelajaran IPA, siswa diharapkan memperoleh sendiri jawaban dari masalah yang mereka alami sedikit demi sedikit dengan memanfaatkan alam sekitarnya. Dalam hal ini para guru diharapkan mengetahui dan mengerti tentang hakikat pembelajaran IPA. Hakikat pembelajaran IPA dapat diklasifikasikan menjadi tiga yaitu ilmu pengetahuan alam sebagai produk, proses, dan sikap ilmiah. Pembelajaran IPA pada usia sekolah dasar harus benar-benar dilakukan secara mendasar dan nyata. Melalui pendidikan IPA diharapkan dapat menumbuhkan kemampuan berpikir logis, rasional, analisis, dan kritis pada siswa dalam rangka mendukung perkembangan ilmu pengetahuan dan teknologi.

Pelaksanaan pembelajaran IPA saat ini belum sesuai dengan apa yang diharapkan. Hal ini dikarenakan masih banyak kendala-kendala yang dihadapi. Salah satu kendala yang paling mempengaruhi adalah guru. Susanto (2013) menyatakan masalah yang dihadapi dunia pendidikan saat ini adalah masalah lemahnya pelaksanaan proses pembelajaran yang diterapkan guru di sekolah. Pelaksanaan proses pembelajaran yang berlangsung di kelas hanya diarahkan pada kemampuan siswa untuk menghafal informasi, dan siswa hanya dipaksa untuk mengingat dan menimbun informasi tanpa dituntut untuk memahami informasi yang diperoleh untuk menghubungkannya dengan situasi dalam kehidupan sehari-hari. Kondisi ini juga terjadi pada pembelajaran IPA yaitu memperlihatkan bahwa selama ini proses pembelajaran IPA di Sekolah Dasar masih banyak yang dilaksanakan secara konvensional. Pembelajaran konvensional menekankan pada belajar ingatan (menghafal) dan metode ceramah mendominasi kegiatan belajar mengajar. Dapat dikatakan bahwa pembelajaran konvensional hanya berpusat pada guru dan tidak memberikan kesempatan bagi siswa untuk berkembang dan menggali pengetahuannya sendiri.

Permasalahan pembelajaran yang telah dipaparkan di atas, mengakibatkan anak tidak mampu untuk mengembangkan pola berpikir. Selain itu, daya kreativitas, imajinasi, seta inovasi siswa akan terkekang, dan motivasi siswa dalam mengikuti pelajaran tersebut akan berkurang, sehingga mengakibatkan situasi pembelajaran yang membosankan bagi siswa. Jika situasi pembelajaran IPA dilaksanakan seperti kondisi tersebut, maka akan mengakibatkan rendahnya hasil belajar IPA siswa, sehingga pada akhirnya tujuan pembelajaran tidak akan tercapai.

Untuk mengatasi rendahnya hasil belajar siswa, maka perlu adanya solusi yang dapat mengubah proses pembelajaran yang awalnya belajar hanya berpusat pada guru menjadi belajar berpusat pada siswa. Salah satu cara yang efektif dilakukan untuk mengatasi kelemahan-kelemahan tersebut adalah dengan menerapkan model 
pembelajaran kooperatif tipe Course Review Horay. Selain harus menggunakan model pembelajaran yang tepat di dalam kelas. Penggunaan media yang tepat juga memiliki peranan penting dalam proses pembelajaran. Kegunaan dan manfaat media dalam proses pembelajaran sangat menguntungkan dalam penyampaian pesan kepada penerima pesan. Contoh dari media yang dapat membantu jalannya proses pembelajaran pada muatan materi IPA adalah question card, quesion card memberikan siswa pertanyaan-pertanyaan melalui kartu yang diberikan oleh guru pada saat pelajaran berlangsung. Dengan menggunakan media ini siswa diharapkan mampu menjadi aktif dan juga mampu meningkatkan rasa ingin tahu siswa untuk mencari jawaban-jawaban dari soal-soal yang diberikan oleh guru pada saat proses pembelajaran.

Hasil belajar adalah kemampuan atau tingkat keberhasilan yang dimiliki oleh siswa setelah mengikuti kegiatan belajar yang menyebabkan perubahan tingkah laku pada orang tersebut, misalnya dari tidak tahu menjadi tahu, dan dari tidak bisa menjadi bisa. Perubahan perilaku yang dialami siswa mencangkup semua aspek, tidak hanya kognitif atau pengetahuannya, namun juga mencangkup aspek afektif, dan psikomotorik. Hasil belajar IPA diperoleh setelah mengikuti proses belajar. Melalui proses belajar terjadi suatu perubahan tingkah laku. Perubahan tingkah laku diperoleh sesuai dengan materi IPA yang telah dipelajari, baik prubahan pada ranah kognitif, afektif maupun psikomotor. Sumber belajar dalam IPA tidak hanya terdapat pada buku dan guru. Namun, sumber belajar IPA bisa didapatkan melalui interaksi langsung dengan alam sekitarnya.

Hasil belajar dijadikan kriteria dalam ketercapaian tujuan pembelajaran. Pencapaian tujuan pembelajaran di dalam kelas tidak terlepas dari faktor-faktor yang memengaruhi hasil belajar itu sendiri.

Faktor - faktor yang memengaruhi hasil belajar yaitu: faktor internal dan faktor eksternal. 1) Faktor internal merupakan faktor yang bersumber dari dalam diri peserta didik. Faktor internal ini meliputi: kecerdasan, minat dan perhatian, motivasi belajar, ketekunan, sikap, kebiasaan belajar, serta kondisi fisik dan kesehatan, 2) Faktor eksternal merupakan faktor yang berasal dari luar diri peserta didik yang mempengaruhi hasil belajar. Faktor eksternal ini meliputi: keluarga, sekolah, dan masyarakat. Keadaan keluarga yang memiliki kemampuan ekonomi redah, perhatian orangtua yang kurang terhadap anaknya berpengaruh terhadap hasil belajar peserta didik. Sekolah juga mempengaruhi hasil belajar siswa, semakin tinggi kemampuan belajar siswa dan kualitas pengajaran di sekolah, maka semakin tinggi pula hasil belajar siswa. Kemudian lingkungan mempengaruhi hasil belajar, siswa yang tinggal dalam kondisi masyarakat yang tidak baik, anggota masyarakat yang sering mabuk-mabukkan, dan tindakantindakan lain yang kurang sesuai dapat menjadikan seorang siswa meniru hal-hal tersebut yang nantinya akan berdampak pada perubahan perilaku siswa ke arah negatif.

Marsetio (dalam Trianto, 2010:137) menyatakan "pada hakikatnya IPA dibangun atas dasar produk ilmiah, proses ilmiah, dan sikap ilmiah". Selain itu, IPA dipandang pula sebagai proses, sebagai produk, dan sebagai prosedur. Sebagai proses diartikan semua kegiatan ilmiah untuk menyempurnakan pengetahuan tentang alam maupun untuk menemukan pengetahuan baru. Sebagai produk diartikan sebagai hasil proses, berupa pengetahuan yang diajarkan dalam sekolah atau di luar sekolah ataupun bahan bacaan untuk penyebaran pengetahuan. Sebagai prosedur diartikan sebagai metodologi atau cara yang dipakai untuk mengetahui sesuatu atau yang lazim disebut metode ilmiah. Tujuan yang ingin dicapai dari pembelajaran IPA adalah membina anak untuk mengembangkan pengetahuan dan pemahaman konsep IPA, memberikan keterampilan, dan menumbuhkan sikap ilmiah anak yang nantinya dapat diterapkan dalam kehidupan sehari-hari dalam memecahkan suatu masalah dan membuat keputusan.

Pembelajaran kooperatif tidak sama dengan sekedar belajar dalam kelompok. Ada unsur-unsur dasar pembelajaran kooperatif yang membedakannya dengan pembagian kelompok yang dilakukan asal-asalan. Pelaksanaan prosedur model pembelajaran kooperatif dengan benar akan memungkinkan guru mengelola kelas lebih efektif. Model pembelajaran kooperatif akan dapat menumbuhkan pembelajaran efektif yaitu pembelajaran yang bercirikan: (1) "memudahkan siswa belajar" sesuatu yang 
"bermanfaat" seperti, fakta, keterampilan, nilai, konsep, dan bagaimana hidup serasi dengan sesama; (2) pengetahuan, nilai, dan keterampilan diakui oleh mereka yang berkompeten menilai (Suprijono 2009). Model pembelajaran kooperatif adalah suatu kerangka konseptual yang terstruktur dan sistematis, dimana melibatkan siswa bekerja sama untuk menemukan dan memahami konsep. Dalam pelaksanaan model pembelajaran kooperatif, siswa secara rutin bekerja dalam kelompok untuk saling membantu memecahkan masalah-masalah yang kompleks, dengan pembelajaran kooperatif ini maka aspek sosial sangat diperhitungkan dalam pembelajaran. Ketika pembelajaran kooperatif ini berlangsung akan memudahkan siswa belajar dengan kelompok-kelompok kecil yang heterogen baik kemampuan maupun jenis kelaminnya. Hal ini bertujuan untuk memberikan kesempatan kepada semua siswa saling terlibat secara aktif dalam proses berpikir dan belajar untuk mencapai tujuan pembelajaran.

Shoimin (2014:54) menyatakan bahwa "model pembelajaran course review horay merupakan salah satu pembelajaran kooperatif, yaitu kegiatan belajar mengajar dengan cara pengelompokan siswa ke dalam kelompok-kelompok kecil". Pembelajaran ini merupakan suatu pengujian terhadap pemahaman konsep siswa menggunakan kotak yang diisi dengan soal dan diberi nomor untuk menuliskan jawabannya. Siswa yang paling terdahulu mendapatkan tanda benar langsung berteriak horay atau yel-yel lainnya. Melalui pembelajaran course review horay diharapkan dapat melatih siswa dalam menyelesaikan masalah dengan pembentukan kelompok kecil.

Kurniasih \& Berlin (2015:80) menyatakan bahwa "model pembelajaran course review horay merupakan model pembelajaran yang dpaat menciptakan suasana kelas menjadi meriah dan menyenangkan, karena setiap siswa yang dapat menjawab benar maka siswa tersebut diwajibkan berteriak horay atau yel-yel lainnya yang disepakati". Sementara itu, Sugandi dan Sri Rahayu (2012:8) menyatakan bahwa "course review horay merupakan salah satu pembelajaran kooperatif yang dalam kegiatan belajar mengajar dilakukan dengan cara pengelompokkan siswa kedalam kelompok-kelompok kecil". Kelompok paling dulu mendapatkan tanda benar langsung berteriak "horay". Model ini dapat mendorong siswa lebih berperan aktif dalam belajar serta tetap dalam bimbingan guru, agar pembelajaran berjalan aktif.

Langkah-langkah pembelajaran model course review horay adalah sebagai berikut. 1) Kegiatan Awal: Fase 1 : Menyampaikan tujuan pembelajaran dan mempersiapkan peserta didik. Guru menyampaikan kompetensi yang ingin dicapai. 2) Kegiatan Inti Fase 2 : Menyajikan informasi a) Guru menyajikan atau mendemonstrasikan materi, b) Guru memberikan kesempatan siswa untuk tanya jawab. Fase 3 : Mengorganisasikan peserta didik dalam tim-tim belajar. a) Guru membagi siswa dalam kelompok-kelompok belajar, b) Guru menyuruh siswa membuat kotak 9/16/25 sesuai dengan kebutuhan dan tiap kotak diisi angka sesuai dengan selera masing-masing siswa. c) Guru membacakan soal dan siswa menuliskan jawaban dalam kotak yang nomornya disesuaikan dengan nomor soal. Fase 4 : Membantu kerja tim dan belajar. a) Guru dan siswa mendiskusikan dan membahas soal yang telah di berikan, b) Jika benar maka diberi tanda benar $(\sqrt{ })$ dan jika salah maka diisi tanda (X), c) Bagi kelompok yang mendapat tanda benar $(\sqrt{ })$ secara vertikal atau horizontal ataupun diagonal secara langsung berteriak "horay" atau menyanyikan yel kelompoknya. Fase 5 : Mengevaluasi. Guru menghitung nilai siswa dihitung dari jawaban benar dan jumlah "horay" yang diperoleh. 3)Penutup.Fase 6 : Memberikan pengakuan dan penghargaan. Guru memberikan reward pada kelompok yang memperoleh nilai tertinggi atau banyak memperoleh "horay".

Setiap model pembelajaran dan metode pembelajaran yang manapun pasti memiliki kelebihan dan kelemahan. Kurniasih \& Berlin (2015:81) menyatakan kelebihan model pembelajaran course review horay adalah sebagai berikut,

Kelebihannya yaitu a) Pembelajarannya menarik dan mendorong siswa untuk dapat terjun kedalamny, b) Pembelajarannya tidak monoton karena diselingi sedikit hiburan sehingga suasana tidak menegangkan, c) Siswa lebih semnagat belajar karena suasana pembelajaran berlangsung menyenangkan, d) melatih kerjasama antar siswa di dalam 
kelas. Sedangkan kelemahan model pembelajaran course review horay a) Siswa aktif dan pasif nilainya disamakan, b) Adanya peluang untuk curang.

Selain penggunaan model pembelajaran yang sesuai dengan karakteristik siswa perlu memperhatikan penggunaan media pembelajaran. Ardani (dalam Handayani dkk, 2017) menyatakan bahwa "media pembelajaran question card atau kartu soal merupakan media visual yang berupa kertas berukuran $10 \times 10 \mathrm{~cm}$, isi dari kartu ini adalah soal-soal yang berkaitan dengan materi pelajaran yang akan dibahas". Sedangkan, menurut Said (2015:264) menyatakan bahwa "media kartu soal adalah jenis permainan dalam pembelajaran menggunakan media kartu yang disajikan berdasarkan nomor kartu pada kartu dan dimainkan secara berkelompok oleh beberapa siswa". Sedangkan Isti Hidayah, dkk (dalam Wisnu, 2016) menyatakan bahwa "media kartu soal merupakan media pembelajaran dna termasuk media visual yang di dalamnya berisi soal-soal untuk membantu guru dalam mengajar".

Rini (2017) dalam penelitian nya menyatakan bahwa Model pembelajaran Course Review Horay Berbasis Pendekatan Problem-Based Learning Berpengaruh terhadap kemampuan berpikir kritis siswa. Model Pembelajaran Course Review Horay Berbasis Pendekatan Problem-Based Learning berpengaruh signifikan terhadap hasil belajar siswa pada ranah kognitif, berpengaruh hasil belajar ranah afektif siswa antara kelas kontrol dan kelas eksperimen dan berpengaruh terhadap hasil belajar ranah psikomotor siswa.

Belina (2018) membuktikan bahwa model pembelajaran kooperatif tipe Course Review Horay dapat meningkatkan hasil belajar siswa. Selain itu model pembelajaran kooperatif tipe ini dikenal sebagai model pembelajaran yang dapat membantu siswa mengingat kembali pelajaran dengan cara menyenangkan sehingga dapat meningkatkan daya ingat siswa.

Berdasarkan uraian di atas, untuk memaksimalkan hasil belajar siswa, peneliti menerapkan model pembelajaran kooperatif tipe course review horay dalam pembelajaran IPA dengan melakukan penelitian yang berjudul "Pengaruh Model Pembelajaran Kooperatif Tipe Course Review Horay Berbantuan Media Question Card Terhadap Hasil Belajar IPA Pada Siswa Kelas III SD Gugus I Rinjani Kecamatan Melaya Kabupaten Jembrana Tahun Pelajaran 2017/2018".

\section{Metode}

Penelitian ini bertujuan untuk mengetahui perbedaan yang signifikan model pembelajaran course review horay berbantuan media question card terhadap hasil belajar IPA siswa. Penelitian ini dilaksanakan pada siswa kelas III SD Gugus I Rinjani Kecamatan Melaya Kabupaten Jembrana Tahun Pelajaran 2017/2018. Penelitian ini merupakan penelitian eksperimen. Penelitian eksperimen ini merupakan penelitian yang gejalanya secara sengaja diadakan oleh peneliti. Pada penelitian yang akan dilakukan tidak memungkinkan untuk mengadakan kontrol/manipulasi terhadap semua variabel yang relevan. Penelitian ini termasuk penelitian eksperimen semu (quasi experiment) karena penugasan subjek ke dalam kelompok eksperimen dan kelompok kontrol tidak dapat dilakukan secara random. Penelitian ini mengikuti desain penelitian quasi experiment dengan rancangan non-equivalent control group design.

Pembelajaran pada kelompok eksperimen menerapkan model pembelajaran course review horay berbantuan media question card sedangkan pada kelompok kontrol Tidak mendapatkan perlakuan model pembelajaran course review horay berbantuan media question card tetapi, mendapatkan pembelajaran yang secara natural berlangsung saat pembelajaran berlangsung. Data hasil belajar IPS diambil dari skor post-test.

Populasi dalam penelitian ini adalah semua siswa kelas III SD di Gugus I Rinjani Kecamatan Melaya yang berjumlah 5 sekolah. Adapun sebaran kelas III di Gugus I Rinjani Kecamatan Melaya dapat dilihat pada Tabel 1 
Tabel 1. Data Siswa Kelas III SD Gugus I Rinjani Kecamatan Melaya

\begin{tabular}{ccc}
\hline No & Nama Sekolah & Jumlah siswa \\
\hline 1 & SDN 1 Gilimanuk & 15 \\
2 & SDN 2 Gilimanuk & 24 \\
3 & SDN 3 Gilimanuk & 25 \\
4 & SDN 4 Gilimanuk & 20 \\
5 & MIN 1 Gilimanuk & 30 \\
& Total Populasi & 114 \\
\hline
\end{tabular}

Untuk mengetahui kesetaraan kemampuan akademik siswa kelas III SD Gugus I Rinjani Kecamatan Melaya Kabupaten Jembrana menggunakan uji kesetaraan ini dilakukan dengan menganalisis nilai hasil belajar IPA. Analisis yang digunakan dalam uji kesetaraan yaitu analisis varians satu jalur (ANAVA A). Kriteria pengujian, jika $F_{\text {hitung }}>$ $\mathrm{F}_{\text {tabel, }}$ maka $\mathrm{H}_{0}$ ditolak dan $\mathrm{H}_{1}$ diterima sehingga kelompok tersebut diinterpretasikan tidak setara. Jika $\mathrm{F}_{\text {hitung }}<\mathrm{F}_{\text {tabel, }}$ maka $\mathrm{H}_{0}$ diterima dan $\mathrm{H}_{1}$ ditolak, maka kelompok tersebut setara. Berdasarkan hasil analisis dengan taraf signifikansi $5 \%$ diperoleh nilai $F_{\text {hitung }}$ sebesar 1,76 dan nilai $F_{\text {tabel }}$ pada $\mathrm{db}_{\text {antar }}=4$ dan $\mathrm{db}_{\text {dalam }}=109$ adalah 2,53. Dengan demikian, $F_{\text {hitung }}$ lebih kecil dari $F_{\text {tabel }}\left(F_{\text {hitung }}<F_{\text {tabel }}\right)$, maka $H_{0}$ diterima. Jadi, tidak terdapat perbedaan hasil belajar IPA siswa kelas III SD di Gugus I Rinjani Kecamatan Melaya Kabupaten Jembrana atau dengan kata lain kemampuan siswa kelas III SD di Gugus I Rinjani Kecamatan Melaya Kabupaten Jembrana adalah setara.

Pengambilan sampel dilakukan menggunakan teknik random sampling. Hasil dari random didapatkan dua kelas sebagai sampel penelitian yaitu, kelas III SDN 2 Gilimanuk yang berjumlah 24 siswa sebagai kelompok eksperimen dan SDN 4 Gilimanuk yang berjumlah 20 siswa sebagai kelompok kontrol.

Variabel penelitian ini terdiri dari variabel bebas (independen) dan variabel terikat (dependen). Variabel bebas dalam penelitian ini adalah model pembelajaran kooperatif tipe think pair share berbantuan media gambar yang diterapkan pada kelas eksperimen. Sedangkan variabel terikat dalam penelitian adalah hasil belajar IPA yang berkaitan dengan aspek kognitif siswa kelas III Gugus I Rinjani Kecamatan Melaya Kabupaten Jembrana Tahun Pelajaran 2076/2018 yaitu berupa pengetahuan yang dimiliki siswa setelah mengalami proses pembelajaran IPA.

Data yang dikumpulkan dalam penelitian ini meliputi hasil belajar IPA. Kegiatan pengumpulan data dilakukan pada siswa kelas III di sekolah yang telah menjadi sampel penelitian. Data hasil belajar siswa ini dikumpulkan dengan satu metode, yaitu metode tes. Agung (2014:92) menyatakan, metode tes dalam kaitannya dengan penelitian ialah cara memperoleh data yang berbentuk suatu tugas yang harus dikerjakan oleh seseorang atau sekelompok orang yang dites (testee), dan dari tes dapat menghasilkan suatu skor (interval). Hasil belajar diukur dengan tes pilihan ganda (soal objektif) yang telah diuji validitas, reliabilitas, daya beda dan tingkat kesukaran.

Metode analisis data dalam penelitian ini menggunakan metode analisis statistik deskriptif dan inferensial. Analisis deskriptif dilakukan untuk mengetahui tinggi rendahnya kualitas hasil belajar siswa, baik yang belajar dengan menggunakan model kooperatif tipe course review horay maupun yang tidak menggunakan model kooperatif tipe course review horay.

Statistik inferensial digunakan menguji kebenaran hipotesis penelitian. Statistik inferensial yang digunakan untuk menguji hipotesis adalah teknik analisis uji-t. Teknik analisis uji-t dapat digunakan jika telah memenuhi uji prasyarat, yaitu sebaran data berdistribusi normal dan homogeny 


\section{Hasil dan Pembahasan}

Deskripsi data hasil penelitian memaparkan tentang mean, median, modus, standar deviasi dan varian berdasarkan data hasil belajar IPA siswa kelas III SD Negeri 2 Gilimanuk yang belajar menggunakan model pembelajaran kooperatif tipe course review horay berbantuan media question card dan pada kelompok kontrol siswa kelas III SD Negeri 4 Gilimanuk yang tidak menggunakan model pembelajaran course review horay.

Data hasil penelitian yang dianalisis adalah data berbentuk skor. Jumlah soal Posttest dilakukan dengan memberikan soal pilihan ganda yang berjumlah 25 soal yang telah divalidasi. Jumlah siswa yang dianalisis data hasil belajar IPA pada kelompok eksperimen adalah 24 orang siswa dan pada kelompok kontrol berjumlah 20 orang siswa

Deskripsi hasil penelitian data hasil belajar IPA siswa memaparkan mean, median, modus, varians dan standar deviasi. Hasil deskripsi data dapat dilihat pada Tabel2.

Tabel 2. Deskripsi Data Hasil Belajar IPA

\begin{tabular}{lcc}
\hline Hasil Analisis & Kelompok Eksperimen & Kelompok kontrol \\
\hline Mean & 19,08 & 12,9 \\
Median & 19,64 & 12,5 \\
Modus & 20,66 & 11,83 \\
Varians & 8,34 & 5,67 \\
Standar Deviasi & 2,88 & 2,38 \\
\hline
\end{tabular}

Berdasarkan diatas dapat dideskripsikan nilai dari mean (M), median (Md), modus (Mo), varians, dan standar deviasi (s) dari data hasil belajar IPA kelompok eksperimen, yaitu mean $(M)=19,08$, median $(M d)=19,64$, modus $(M o)=20,66$, varians $\left(s^{2}\right)=8,34$ dan standar deviasi $(s)=2,88$.

Mean (M), median (Md), modus (Mo) hasil belajar IPA siswa kelompok eksperimen selanjutnya disajikan ke dalam kurva poligon. Tujuan menyajikan data ini adalah untuk mendeskripsikan sebaran data hasil belajar IPA pada kelompok eksperimen. Hubungan antara Mean (M), median (Md), dan modus (Mo) dapat digunakan untuk menentukan kemiringan kurva poligon distribusi frekuensi. Data hasil belajar IPA kelompok eksperimen disajikan ke dalam bentuk kurva poligon seperti pada Gambar 1.

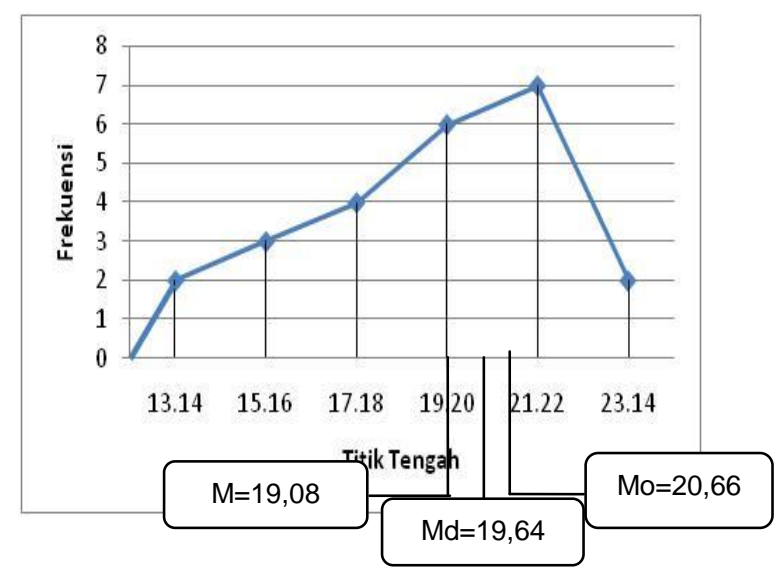

Gambar 1. Kurva Poligon Data Hasil Belajar Kelompok Eksperimen

Berdasarkan kurva poligon data hasil belajar kelompok eksperimen di atas, dapat diketahui bahwa modus lebih besar dari mean dan mean lebih besar dari median $(\mathrm{Mo}>\mathrm{Md}>\mathrm{M})$. Dengan kata lain, kurva di menunjukkan kurva juling negatif. Artinya, 
sebagian besar skor cenderung tinggi. Kecenderungan skor ini dapat dibuktikan dengan melihat frekuensi relatif pada tabel distribusi frekuensi. Frekuensi relatif skor yang berada di atas rata-rata lebih besar dibandingkan frekuensi relatif skor yang berada di bawah rata-rata.

Mean (M), median (Md), modus (Mo) hasil belajar IPA siswa kelompok kontrol selanjutnya disajikan ke dalam kurva poligon. Tujuan menyajikan data ini adalah untuk mendeskripsikan sebaran data hasil belajar IPA pada kelompok kontrol. Hubungan antara Mean (M), median (Md), dan modus (Mo) dapat digunakan untuk menentukan kemiringan kurva poligon distribusi frekuensi. Data hasil belajar IPA kelompok kontrol disajikan ke dalam bentuk kurva poligon seperti pada Gambar 2.

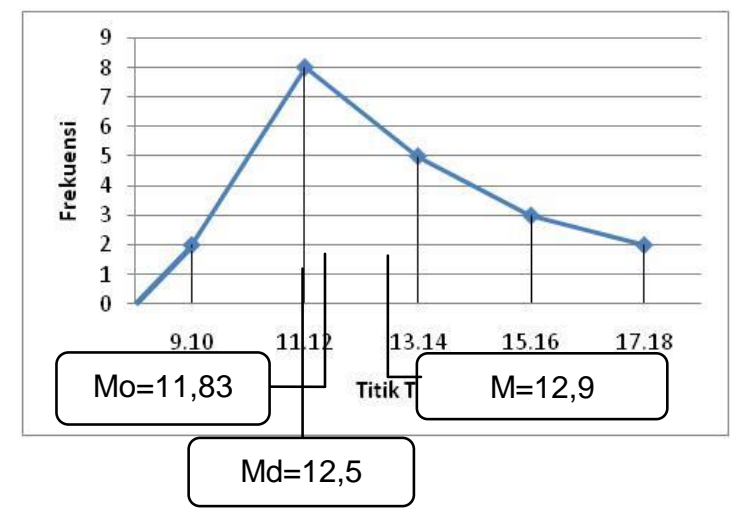

Gambar 2. Kurva Poligon Data Hasil Belajar Kelompok Kontrol

Berdasarkan kurva poligon data hasil belajar kelompok kontol di atas, dapat diketahui bahwa modus lebih kecil dari mean dan mean lebih kecildari median $(\mathrm{Mo}<\mathrm{Md}<\mathrm{M})$. Dengan kata lain, kurva di menunjukkan kurva juling positif. Artinya, sebagian besar skor cenderung rendah. Kecenderungan skor ini dapat dibuktikan dengan melihat frekuensi relatif pada tabel distribusi frekuensi. Frekuensi relatif skor yang berada di atas rata-rata lebih kecil dibandingkan frekuensi relatif skor yang berada di bawah ratarata.

Uji normalitas sebaran data dilakukan untuk mengetahui apakah data yang diperoleh berdistribusi normal atau tidak. Jika berdistribusi normal maka uji hipotesis dapat dilakukan bantuan program Microsoft Office Excel 2007 for Windows dapat disajikan hasil uji normalitas sebaran data hasil belajar IPA kelompok eksperimen dan kontrol pada Tabel 3

Tabel 3. Rangkuman Hasil Uji Normalitas Sebaran Data

\begin{tabular}{clll}
\hline No Kelompok Data Hasil Belajar IPA & $\chi^{2}{ }_{\text {hitung }}$ & $\chi^{2}{ }_{\text {tabel }}$ & keterangan \\
\hline Post-test Eksperimen & 2,485 & 7,815 & Normal \\
Post-test Kontrol & 2,300 & 5,591 & Normal \\
\hline
\end{tabular}

Kriteria pengujian, jika $\chi^{2}{ }_{h i t}<\chi_{\text {tab }}^{2}$ dengan taraf signifikasi 5\% (dk = jumlah kelas dikurangi parameter, dikurangi 1), maka data berdistribusi normal. Sedangkan, jika $\chi_{h i t}^{2} \geq \chi_{t a b}^{2}$, maka sebaran data tidak berdistribusi normal. Berdasarkan hasil perhitungan degan menggunakan rumus chi-kuadrat, diperoleh $\chi^{2}$ hit hasil post-test kelompok eksperimen adalah 2,485 dan $\chi^{2}$ tab dengan taraf signifikasi $5 \%$ dan $\mathrm{db}=3$ adalah 7,815 . Hal ini berarti, $\chi^{2}$ hit hasil post-test kelompok eksperimen lebih kecil dari 
$\chi^{2}{ }_{t a b}\left(\chi_{h i t}^{2}<\chi_{t a b}^{2}\right)$, sehingga data hasil post-test kelompok eksperimen berdistribusi normal. Sedangkan, $\chi^{2}{ }_{\text {hit }}$ hasil post-test kelompok kontrol adalah 2,300 dan $\chi^{2}$ tab dengan taraf signifikansi $5 \%$ dan $\mathrm{db}=2$ adalah 5,591. Hal ini berarti, $\chi^{2}$ hit hasil post-test kelompok kontrol lebih kecil dari $\chi_{t a b}^{2}\left(\chi_{h i t}^{2}<\chi^{2}{ }_{t a b}\right)$, sehingga data hasil post-test kelompok kontrol berdistribusi normal.

Uji homogenitas varians antar kelompok bertujuan untuk memeriksa kesamaan varians antar kelompok perlakuan. Dalam penelitian ini, uji homogenitas dilakukan terhadap varians pasangan antar kelompok eksperimen dan kontrol. Uji yang digunakan adalah uji-F dengan kriteria data homogen jika $F_{\text {hit }}<F_{\text {tab. Rekapitulasi hasil uji }}$ homogenitas varians antar kelompok eksperimen dan kontrol disajikan pada Tabel 4.

Tabel 4. Rangkuman Homogenitas Varians antar Kelompok Eksperimen dan Kontrol

\begin{tabular}{c|c|c|c}
\hline Data & $F_{\text {hitung }}$ & $F_{\text {tabel }}$ & Status \\
\hline $\begin{array}{c}\text { Post-Test Kelompok Eksperimen } \\
\text { dan Kelompok Kontrol }\end{array}$ & 1,47 & 2,16 & Homogen \\
\hline
\end{tabular}

Berdasarkan Tabel di atas, diketahui $F_{\text {hit }}$ hasil kelompok eksperimen dan kontrol adalah 1,47 sedangkan $F_{\text {tab }}$ pada $d_{b_{\text {pembilang }}}=23, \mathrm{db}_{\text {penyebut }}=19$, dan taraf signifikansi $5 \%$ adalah 2,16. Hal ini berarti, varians data hasil belajar IPA kelompok eksperimen dan kontrol adalah homogen. Selanjutnya pengujian hipotesis menggunakan uji-t.

$\mathrm{H}_{0}$ menyatakan tidak terdapat perbedaan hasil belajar IPA yang signifikan antara kelompok siswa yang dibelajarkan menggunakan model pembelajaran kooperatif tipe course review horay berbantuan media question card dan kelompok siswa yang dibelajarkan menggunakan model pembelajaran konvensional pada siswa kelas III SD di Gugus I Rinjani Kecamatan Melaya Kabupaten Jembrana tahun pelajaran 2017/2018.

$\mathrm{H}_{1}$ terdapat perbedaan hasil belajar IPA yang signifikan antara kelompok siswa yang dibelajarkan menggunakan model pembelajaran kooperatif tipe course review horay berbantuan media question card dan kelompok siswa yang dibelajarkan menggunakan model pembelajaran konvensional pada siswa kelas III SD di Gugus I Rinjani Kecamatan Melaya Kabupaten Jembrana tahun pelajaran 2017/2018.

Karena $n_{1} \neq n_{2}$ dan hasil perhitungan varians menyatakan homogen, maka dalam pengujian digunakan rumus polled varians, dengan $\mathrm{db}=\left(\mathrm{n}_{1}+\mathrm{n}_{2}\right)^{-} 2$ dan kriteria tolak $\mathrm{H}_{0}$ jika $t_{\text {hit }}>t_{\text {tab }}$ dan terima $H_{0}$ jika $t_{\text {hit }}<t_{\text {tab }}$. Rangkuman hasil perhitungan uji-t antar kelompok eksperimen dan kontrol Dapat dilihat pada Tabel 5.

Tabel 5. Rangkuman Hasil Perhitungan Uji-T

\begin{tabular}{c|c|c|c|c|c|c}
\hline Kelompok & $\mathrm{N}$ & $\mathrm{Db}$ & Mean & $\mathrm{s}^{2}$ & $\mathrm{t}_{\text {hit }}$ & $\mathrm{t}_{\text {tab }}$ \\
\hline Eksperimen & 24 & 42 & 19,08 & 8,34 & 7,725 & 2,021 \\
\hline
\end{tabular}

Berdasarkan tabel analisis di atas, dapat diketahui $t_{\text {hit }}=7,725$ dan $t_{\text {tab }}=2,021$ untuk $\mathrm{db}=42$ pada taraf signifikansi $5 \%$. Berdasarkan kriteria pengujian, karena $t_{\text {hit }}>t_{\text {tab }}$ maka $\mathrm{H}_{0}$ ditolak dan $\mathrm{H}_{1}$ diterima. Artinya, terdapat perbedaan hasil belajar IPA yang signifikan antara kelompok siswa yang dibelajarkan menggunakan model pembelajaran kooperatif tipe course review horay berbantuan media question card dan kelompok siswa yang dibelajarkan menggunakan model pembelajaran konvensional pada siswa kelas III SD di Gugus I Rinjani Kecamatan Melaya Kabupaten Jembrana tahun pelajaran 2017/2018.

Hasil analisis data hasil belajar menunjukkan bahwa terdapat perbedaan hasil belaja yang signifikanr antara siswa yang dibelajarkan dengan model pembelajaran kooperatif tipe course review horay berbantuan media question card dan kelompok siswa yang dibelajarkan dengan pembelajaran konvensional. Tinjauan ini didasarkan pada hasil 
data post-test siswa dan hasil uji-t. Post-test diberikan setelah adanya perlakuan model pembelajaran kooperatif tipe course review horay berbatuan media question card. Hasil perhitungan menyatakan bahwa hasil post-test kelas eksperimen lebih besar dari kelas kontrol. Hal ini dibuktikan dari rata-rata skor hasil belajar IPA kelas eksperimen dan kelas kontrol. Rata-rata skor kelas eksperimen adalah 19,08 berada pada kategori sangat tinggi, sedangkan rata-rata skor kelas kontrol adalah 12,9 berada pada kategori sedang.

Model pembelajaran kooperatif tipe course review horay berbantuan media question card dapat meningkatkan kemampuan siswa dalam mengingat suatu informasi dan siswa juga dapat belajar dari siswa lain serta melatih siswa untuk mneyampaikan idenya dalam diskusi. Dengan begitu siswa diberi kesempatan untuk berpartisipasi dalam kelompok. Guru tidak lagi sebagai satu-satunya sumber pembelajaran (teacher centered) tetapi justru siswa yang dituntut untuk dapat menemukan dan memahami konsep baru (student centered). Melalui model pembelajaran kooperatif tipe course review horay berbatuan media question card ini siswa dapat meningkatkan hasil belajar siswa. Jadi model pembelajaran kooperatif tipe course review horay berbantuan media question card lebih baik diterapkan untuk meningkatkan hasil belajar IPA siswa dibandingkan dengan model pembelajaran konvensioanl.

Temuan yang menunjukkan bahwa skor rata-rata hasil belajar IPA kelas eskperimen cenderung tinggi disebabkan oleh beberapa hal. Pertama, guru lebih mempersiapkan diri untuk mengajar karena adanya peneliti selama proses pembelajaran berlangsung. Dengan guru mempersiapkan diri dapat dibuktikan bahwa dirinya dapat menjadi guru yang professional. Kedua, siswa menjadi semangat dalam mengikuti pembelajaran karena guru menerapkan pembelajaran baru yang menyenagkan sehingga siswa menjadi termotivasi untuk belajar. Dengan demikian hasil belajar IPA semakin meningkat. Ketiga, keterlibatan peneliti selama proses pembelajaran yang membuat suasana kelas menjadi berbeda dari hasi-hari biasanya. Dengan adanya peneliti selama proses pembelajaran berlangsung sikap siswa mejadi lebih aktif dan siswa bersemanagat untuk mengemukakan pendapatnya serta ingin menunjukkan kemampuanya dalam pembelajaran.

Temuan tersebut didukung oleh penjelasan Kurniasih dan Berlin Sani (2105), yang menyatakan bahwa model pembelajaran kooperatif tipe course review horay merupakan model pembelajaran yang menarik dan menyenangkan karena dalam proses pembelajaran diselingi hiburan sehingga ssiwa lebih semanagat. Hasil penelitian yang diperoleh pada penelitian ini juga sejalan dengan penelitian yang dilakukan oleh Pranata (2017) melakukan penelitian mengenai model pembelajaran kooperatif tipe course review horay dalam pembelajaran IPA mampu memberikan kontribusi yang cukup signifikan terhadap hasil belajar IPA. Hal ini dibuktikan dengan rata-rata kelompok eksperimen $(23,33)$ lebih besar dari rata-rata kelompok kontrol $(17,75)$. Berdasarkan hasil tersebut dapat disimpulkan bahwa nilai rata-rata tes siswa kelas eksperimen lebih besar dibandingkan kelas kontrol dan juga terdapat perbedaan hasil belajar dari kedua kelas tersebut

Hasil penelitian ini juga diperkuat oleh penelitian yang dilakukan oleh Lianto (2016) menunjukkan bahwa rata-rata skor hasil belajar IPA kelompok siswa yang dibelajarkan dengan model pembelajaran course review horay $(19,86)$ lebih tinggi dibandingkan ratarata skor kelompok siswa yang dibelajarkan menggunakan model pembelajaran konvensional $(15,38)$. Berdasarkan hasil tersebut dapat disimpulkan bahwa nilai rata-rata tes siswa kelas eksperimen lebih besar dibandingkan kelas kontrol dan juga terdapat perbedaan hasil belajar dari kedua kelas tersebut.

Berbeda halnya dalam pembelajaran konvensional yang merupakan pembelajaran yang biasa dilakukan oleh guru. Dalam proses pebelajaran terlihat bahwa guru memberikan materi pelajaran melalui metode ceramah, latihan soal-soal kemudian pemberian tugas pada siswa. Dalam pembelajaran konvensioanal yang menjadi pusat pembelajaran adalah guru, sehingga pandangan siswa hanya tertuju pada guru. Hal ini sejalan dengan pendapat Rasana (2009) menyatakan penyampaian materi dalam pembelajaran konvensional lebih banyak dilakukan melalui metode ceramah secara terus 
menerus. Artinya penyajian materi sepenuhnya dilakukan oleh guru sebagai sumber informasi atau pembelajaran dikatakan berpusat pada guru (teacher centered). Dalam pembelajaran konvensional siswa hanya berfungsi sebagai penerima informasi dari guru tanpa adanya hubungan timbal balik antara guru dan siswa.

Perbedaan cara pembelajaran antara kelompok siswa yang dibelajarkan menggunakan model pembelajaran kooperatif tipe course review horay berbatuan media question card dan kelompok siswa yang dibelajarkan menggunakan model pembelajaran konvensional memberikan dampak yang berbeda terhadap hasil belajar siswa. Penerapan model pembelajaran kooperatif tipe course review horay berbantuan media question card dalam pembelajaran memungkinkan siswa untuk tahu manfaat dari materi yang dipelajari bagi kehidupan dan pembelajaran menjadi lebih bermakna, siswa akif dalam pembelajaran, serta dapat menumbuhkan sikap sosial dalam bekerja sama dengan siswa lainnya. Siswa akan senang dalam mengkuti kegiatan pembelajaran karena dalam proses pembelajaran siswa dibentuk menjadi beberapa kelompok untuk untuk menjawab soal yang diajukan oleh guru, dalam menjawab soal inilah menimbulkan nuansa persaingan positif antar kelompok karena setiap kelompok tentunya menginginkan untuk menang dan mendapat skor tertinggi. Sehingga setiap kelompok antusias dalam mendengarkan setiap pertanyaan yang dibacakan oleh guru. Dengan demikian hasil belajar IPA kelompok siswa yang dibelajarkan menggunakan model pembelajaran kooperatif tipe course review horay berbatuan media question card lebih baik dibandingkan dengan kelompok siswa yang dibelajarkan menggunakan model pembelajaran konvensional.

\section{Simpulan dan Saran}

Berdasarkan hasil penelitian dan pembahasan, maka disimpulkan bahwa terdapat perbedaan hasil belajar IPA yang signifikan antara kelompok siswa yang dibelajarkan menggunakan model pembelajaran kooperatif tipe course review horay berbantuan media question card dan kelompok siswa yang dibelajarkan menggunakan model pembelajaran konvensional pada siswa kelas III SD Gugus I Rinjani Kecamatan Melaya Kabupaten Jembrana tahun pelajaran 2017/2018. Hal ini dapat dilihat berdasarkan hasil pengujian hipotesis dengan menggunakan uji-t diperoleh $t_{\text {hitung }} 7,725$ dan $t_{\text {tabel }}$ dengan taraf signifikansi $5 \%$ dan $\mathrm{db}=42$ adalah 2,021 . Ini berarti $t_{\text {hitung }}>\mathrm{t}_{\text {tabel }}$, sehingga $\mathrm{H}_{0}$ ditolak dan $\mathrm{H}_{1}$ diterima. Artinya model pembelajaran kooperatif tipe course review horay berbatuan media question card memiliki pengaruh yang signifikan terhadap hasil belajar IPA siswa kelas III SD Gugus I Rinjani Kecamatan Melaya Kabupaten Jembrana tahun pelajaran 2016/2017.

Saran-saran yang dapat disampaikan berdasarkan penelitian yang telah dilakukan adalah 1) siswa di sekolah dasar agar lebih aktif dalam mengikuti pembelajaran dan terus mengembangkan pemahamannya dengan membangun pengetahuannya sendiri melalui pengalaman sehingga dapat meningkatkan hasil belajar. 2) guru agar lebih berinovasi dan kreatif dalam proses pembelajaran dengan menerapkan model yang sesuai karakteristik siswa, untuk meningkatkan hasil belajar sehingga pembelajaran berlangsung lebih efektif. 3) Kepala Sekolah agar selalu berusaha memfasilitasi guru agar mampu menggunakan berbagai macam model yang bervariasi dalam proses pembelajaran sehingga hasil belajar siswa meningkat.4) Disarankan kepada peneliti lain agar memperhatikan kendala yang dialami dalam pelaksanaan model pembelajaran kooperatif tipe think pair share khususnya dalam ilmu IPS untuk penyempurnaan penelitian yang akan dilaksanakan.

\section{Daftar Pustaka}

Agung, A. A. Gede. 2014. Buku Ajar Metodologi Penelitian Pendidikan. Yogyakarta: Aditya Media Publishing.

Belina Septiara. 2018. Penerapan Model Course Review Horay Untuk Meningkatkan Aktivitas Dan Hasil Belajar Siswa. FKIP Universitas Lampung. 
Handayani, Ni Putu. Ida, dkk. 2017. "Pengaruh Model Pembelajaran TPS (Think Pair Share) Berbantuan Question Card Terhadap Kompetensi Pengetahuan IPA Siswa Kelas V SD Gugus I Gusti Ngurah jelantik Tahun Ajaran 2016/2017". e-Journal Mimbar PGSD Undiksha. Volume 5, Nomor 2.

Kurniasih, Imas dan Berlin Sani. 2015. Ragam Pengembangan Model Pembelajaran untuk Meningkatkan Profesionalitas Guru. Cetakan Ke-1. Kata Pena.

Rini. 2017. Pengaruh Penerapan Model Pembelajaran Course Review Horay Berbasis Pendekatan Problem-Based Learning Terhadap Kemampuan Berpikir Kritis dan Hasil Belajar Biologi. Bioedukasi Vol.XV No.1 April 2017

Said, Alamsyah dan Andi Budimanjaya. 2015. Strategi Mengajar Multiple Intelligences. Jakarta: PRENADAMEDIA GRUP.

Shoimin, Aris. 2014. 68 Model pembelajaran Inovatif Dalam Kurikulum 2013. Cetakan Pertama. Yogyakarta: Ar-Ruzz Media.

Somatowa, Usman. 2010. Pembelajaran IPA Di Sekolah Dasar. Cetakan Pertama. Jakarta Barat: Indeks.

Sugandi, Eko dan Sri Rahayu. 2012. "Upaya Meningkatkan Prestasi Belajar Matematika Pada Pokok Bahasan Sistem Persamaan dan Pertidaksamaan Kuadrat melalui Model Pembelajaran Kooperatif Tipe Course Review Horay pada Siswa Kelas X Akutansi 1 SMK Negeri 1 Surabaya Tahun Ajaran 2011/2012". Makalah disajikan dalam Seminar Nasional Pendidikan Matematika Aplikasi Pendidikan Karakter dalam Pembelajaran Matematika. Universitas PGRI Adi Buana Surabaya, 05 Mei 2012.

Suprijono, Agus. 2009. Cooperatif Learning Teori dan Aplikasi PAIKEM. Yogyakarta: Pustaka Pelajar.

Susanto, Ahmad. 2013. Teori Belajar dan Pembelajaran di Sekolah Dasar. Cetakan Ke-1. Jakarta: Kencana.

Trianto. 2010. Model Pembelajaran Terpadu: Konsep, Strategi, dan Implementasinya dalam Kurikulum Tingkat Satuan Pendidikan (KTSP). Cetakan Ke-2. Jakarta: PT Bumi Aksara.

Wisnu, A. A. Gede Agung, dkk. 2016. "Penerapan Model Pembelajaran Talking Stick Berbantuan Kartu Soal Untuk Meningkatkan Keaktifan Dan Hasil Belajar IPA Siswa Kelas IV SDN 2 Banjar Bali Tahun Ajaran 2015/2016”. e-Journal PGSD Undiksha. Volume 4, Nomor 1.

Wisudawati, Widi Asih dan Eka Sulistyowati. 2015. Metodologi Pembelajaran IPA. Jakarta: Bumi Aksara. 